\title{
Turbinaria foliosa sp. nov. (Fucales, Phaeophyceae) from the Sultanate of Oman, with a census of currently recognized species in the genus Turbinaria
}

\author{
Michael J. Wynne \\ Department of Ecology and Evolutionary Biology and Herbarium, University of Michigan, Ann Arbor, MI 48109, USA
}

\section{SUMMARY}

Turbinaria foliosa sp. nov. is described on the basis of several collections made from Dhofar, Sultanate of Oman. The new species is known only from southern Oman, a region of the northern Arabian Sea that is strongly impacted by the upwelling from the summertime monsoon. It is distinguished from other species of the genus by the shape of the leaves and by their loose, non-congested arrangement. Air vesicles, embedded in the leaves, may be present, but more often are absent. A census of the currently recognized species in the genus Turbinaria is provided. Reference is made to Sargassum turbinarioides and Sargassum turbinatifolium. These species possess discrete blades and spherical vesicles and thus conform to Sargassum.

Key words: brown algae, Fucales, marine algae, new species, Omani flora, taxonomy, Turbinaria, Turbinaria foliosa.

\section{INTRODUCTION}

In recent years, the benthic marine algal flora of the southern coast of the Sultanate of Oman, northern Arabian Sea, has been receiving greater attention. The publication of a number of newly described taxa and new records for this region has resulted (Nizamuddin and Campbell 1995; Wynne 1998, 1999a,b, 2000, 2001a,b, 2002; Wynne and Jupp 1998; Wynne and Leliaert 2001; Wynne and de Jong 2002).

Turbinaria is characterized as having radially branched, monopodially developed axes, bearing leaves, or 'laterals' that have the form of firm, more or less peltate or turbinate structures (Fritsch 1959). The habit of most species is a stiff, compact, cone-like aspect. Typically, these 'leaf-vesicles' are stipitate, turbinate or obpyramidal, and crowned with a peltate lamina (Harvey 1860). In all of the currently known species of Turbinaria, the lateral is terminated by a more or less triangular or rectangular, flat or concave outer face, with possibly one or two edges of teeth, depending on the species. The proximal part of the leaf is terete in most species, but is ridged or winged in some species. Leaves in most species of Turbinaria have an air vesicle embedded within the peltate enlargement. Thalli are usually attached by a well-developed system of spreading hapterous branches emanating from the main axes. Short, densely branched receptacles arise on the upper sides of the stalks of the leaves.

The only two previous records of Turbinaria from Oman are for two formae of Turbinaria ornata (Turner) J. Agardh, namely, f. ecoronata W. R. Taylor (Wynne and Jupp 1998) and f. evesculosa (E. S. Barton) W. R. Taylor (Wynne 2001a). Several collections of a distinctive Turbinaria were made at the end of the monsoon seasons of 2000 and 2001, both as attached and as drift specimens. This alga is described herein as Turbinaria foliosa sp. nov.

\section{MATERIALS AND METHODS}

The specimens were gathered by SCUBA diving as well as by shore-collecting, both attached in shallow water and as drift material. Approximately 50 erect specimens were examined in this study. Most of the collections were processed as herbarium specimens the same day; smaller amounts were preserved in 5\% formalin in seawater. Specimens were deposited in the Natural History Museum, London (BM), the Herbarium of the University of Michigan (MICH), and the Natural History Museum of Oman, Muscat (ON). Additional pressed specimens were deposited in other herbaria as cited. Photocopies of the typus of Sargassum turbinarioides Grunow and accompanying protologue material in the Naturhistorisches Museum Wien (W) were examined. Herbarium abbreviations are according to Holmgren et al. (1990).

\section{RESULTS}

The plants of $T$. foliosa sp. nov. are dark brown and usually $6-15 \mathrm{~cm}$ in height, sometimes to $25 \mathrm{~cm}$ tall. Erect axes (Fig. 1) tend to be simple, percurrent,

Email: mwynne@umich.edu

Communicating editor: H. Kawai.

Received 25 March 2002; accepted 21 August 2002. 


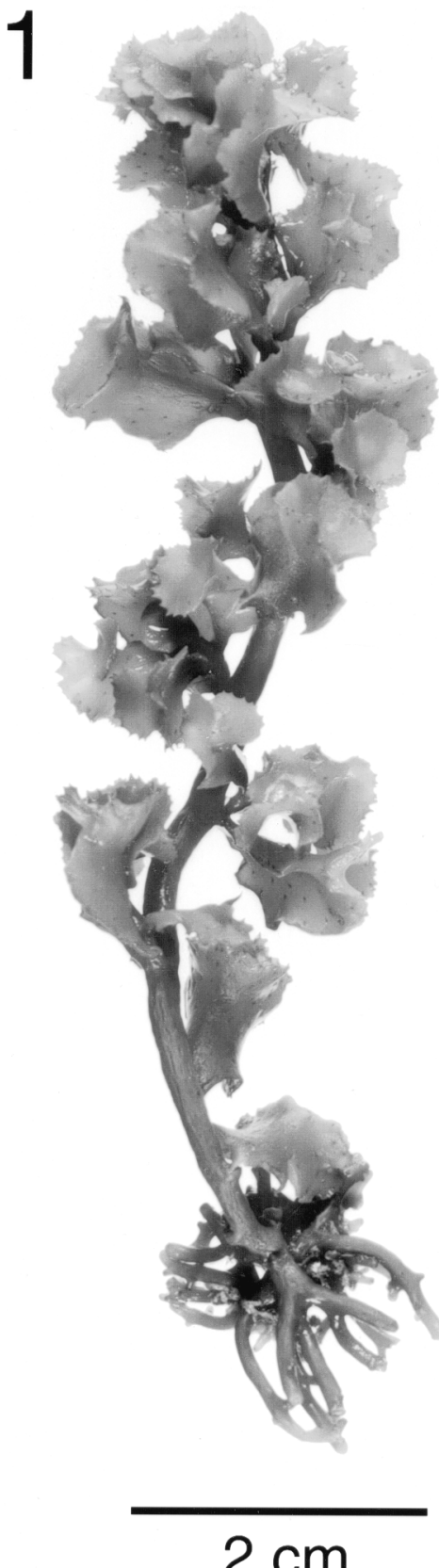

$2 \mathrm{~cm}$

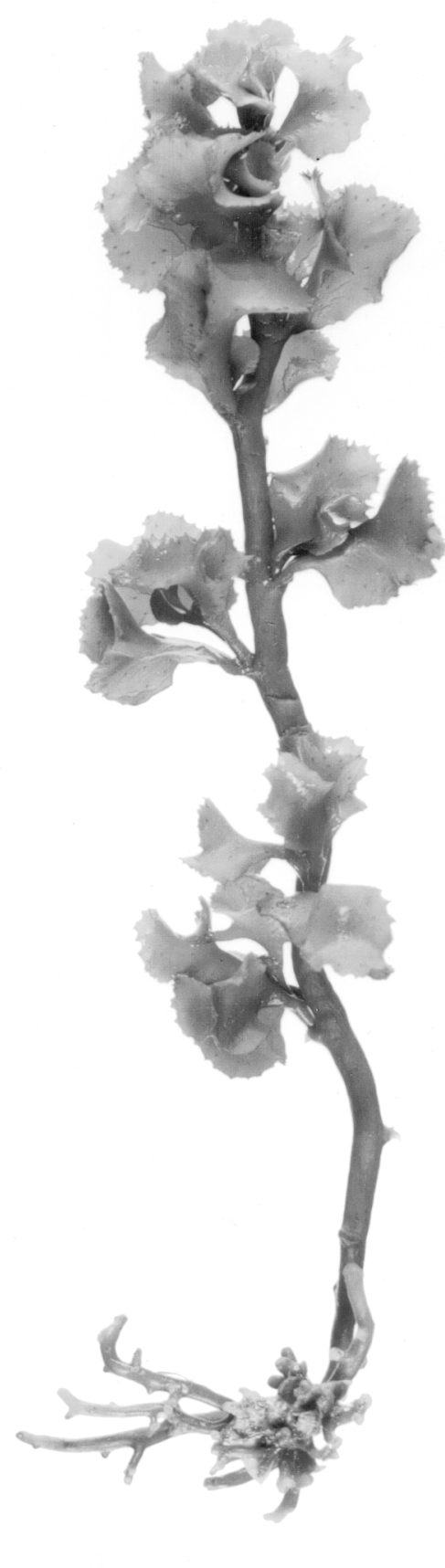

Fig. 1. Turbinaria foliosa. 1. Holotype (coll. 09092001-04-02). Liquid-preserved specimens prior to being pressed. bearing leaves solitary or in clusters (on short branches), loosely spaced along the length of the main axis. Some plants have lateral branches in the lower half of the main axes, these branches bearing three to eight leaves. Main axes are 3-4 $\mathrm{mm}$ in diameter. The erect axes are attached by a holdfast consisting of a loosely organized mass of hapterous axes arising from the lower $1-3 \mathrm{~cm}$ of the main axis. These haptera are $1 \mathrm{~mm}$ in diameter and are irregularly branched, the branch tips attaching to the rock substratum. The individual leaves (Figs 2,3) are firm in texture, 23-26 mm long and $20-25 \mathrm{~mm}$ wide when fully expanded, winged close to the base, flattened, with dentate margins, with the abaxial surface of the leaf often retroflexed. Leaves have a projection on their adaxial surface (Figs 4-9). The extent of the development of this projection is variable. Sometimes (in younger plants) the projection is merely a 'flap' of tissue extending outward (Figs 13-17). In more mature plants, leaves have a well-developed projection that extends perpendicularly from the adaxial surface of the leaf. The outer edges of this projection are rounded or angular, the margins being serrate (Figs 5-9). One edge of the rim of the projection is confluent with the distal edge of the leaf (Fig. 12). Sections of the projections reveal them to range from solid to hollow. 


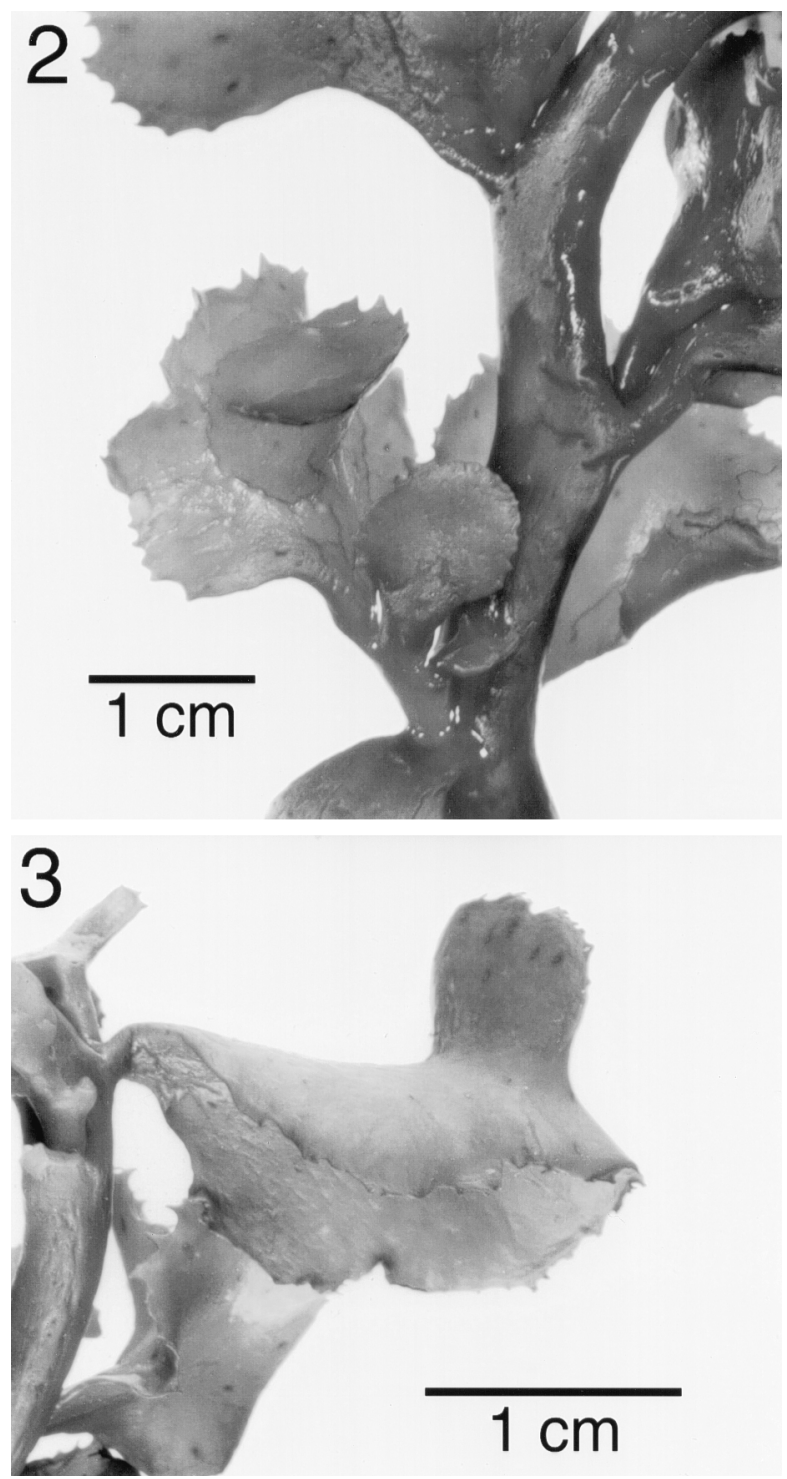

Figs 2, 3. Turbinaria foliosa. Close-up views of leaves of Holotype.

In some, the hollow region is very small (Figs 18,19), and in others, there is a more obvious air vesicle embedded in the projection (Figs 10,11). Receptacles were not present.

\section{Diagnosis}

\section{Turbinaria foliosa M. J. Wynne sp. nov.}

Plantae atrofuscae, plerumque $6-15 \mathrm{~cm}$ altae, interdum $25 \mathrm{~cm}$ altae, caules subsimplices et percurrentes, interdum ramis lateralibus in dimidio inferiore axis principalis; axes principales 3-4 $\mathrm{mm}$ in diametro, per hapteron laxe ramos dispositos affixi, $1 \mathrm{~mm}$ in diam. et irregulariter ramosos; folia singulatim vel in collectione (in ramis brevibus) laxa secus longitudinem axis principalis portata; singula folia firma, 23-26 mm longa et
20-25 mm lata ubi plene expansa, prope basem alata, complanata, marginibus dentatis, pagina abaxiali folii retroflexa; folia interdum pneumatocysta inclusa, in parte distali paginae adaxalis; receptacula adsunt.

Plants dark brown, usually $6-15 \mathrm{~cm}$ tall, at times to $25 \mathrm{~cm}$ tall, axes subsimple and percurrent, sometimes with lateral branches in the lower half of the principal axis; principal axes 3-4 $\mathrm{mm}$ in diameter, attached by a holdfast with loosely arranged branches, $1 \mathrm{~mm}$ in diameter and irregularly branched; leaves borne singly or in clusters (on short branches), loosely spaced along the length of the main axis; individual leaves firm, 23-26 mm long and 20-25 mm wide when fully expanded, winged close to the base, flattened, with dentate margins, with the abaxial surface of the leaf often retroflexed; receptacles absent.

Holotypus: Sultanate of Oman. Western side of Wadi Zeid (Hoon's Bay) $16.944967^{\circ} \mathrm{N}, 54.80402^{\circ} \mathrm{E}$, east of Mirbat, Dhofar: 9.ix.2001, leg. G. Richards and M. Wynne 09092001-04-02, attached to boulders at 3-5-m depth and in drift. Deposited in $\mathrm{MICH}$.

Isotypes: deposited in BM, GENT, ON, PC, and US.

Etymology: 'foliosa' alludes to the broadly foliose appearance of the leaves rather than the more common modified turbinate or peltate appearance in other species of the genus.

Additional collections. Type locality: 10.ix.2000, leg. G. Richards and M. Wynne 10092000-03-21, attached at 3-5-m depth and in drift (BM, $\mathrm{MICH}, \mathrm{ON}$ ). Exposed shoreline between Hino and western side of Wadi Zeid (= Hoon's Bay) $\left(16.953817^{\circ} \mathrm{N}, 54.780350^{\circ} \mathrm{E}\right)$, east of Mirbat, Dhofar: 28.ix.2001, leg. G. Richards and M. Wynne 28092001-25-02, attached, shallow water. Deposited in $\mathrm{BM}, \mathrm{MICH}, \mathrm{ON}$, and US.

Ecology: The shoreline with the only two collection sites of the new Turbinaria is subjected to heavy surf exposure during the summertime monsoon. Hoon's Bay (the type locality) is a sheltered cove, but still experiences great swells. These plants, reaching $25 \mathrm{~cm}$ in height, were growing attached at 3-5 $\mathrm{m}$ and were also found cast up. A noteworthy feature of the ecology of $T$. foliosa is that the plants occur in very localized patches, colonizing openings in a 'canopy' of other, larger and more dense, brown algae such as Nizamuddinia zanardinii (Schiffner) P. C. Silva. At times plants were growing on the tops of boulders, elevated above the seabed, possibly a vantage point above the shading from other algae.The second site, between Hoon's Bay and the town of Hino, is a very rocky, wave-battered stretch of coastline, and here the plants were growing in very shallow tide pools, almost exposed. These plants were only $12-14 \mathrm{~cm}$ in height. This size difference is pointed out, despite the collections being made in the same month, the smaller stature apparently being correlated with the more exposed conditions of this site. 

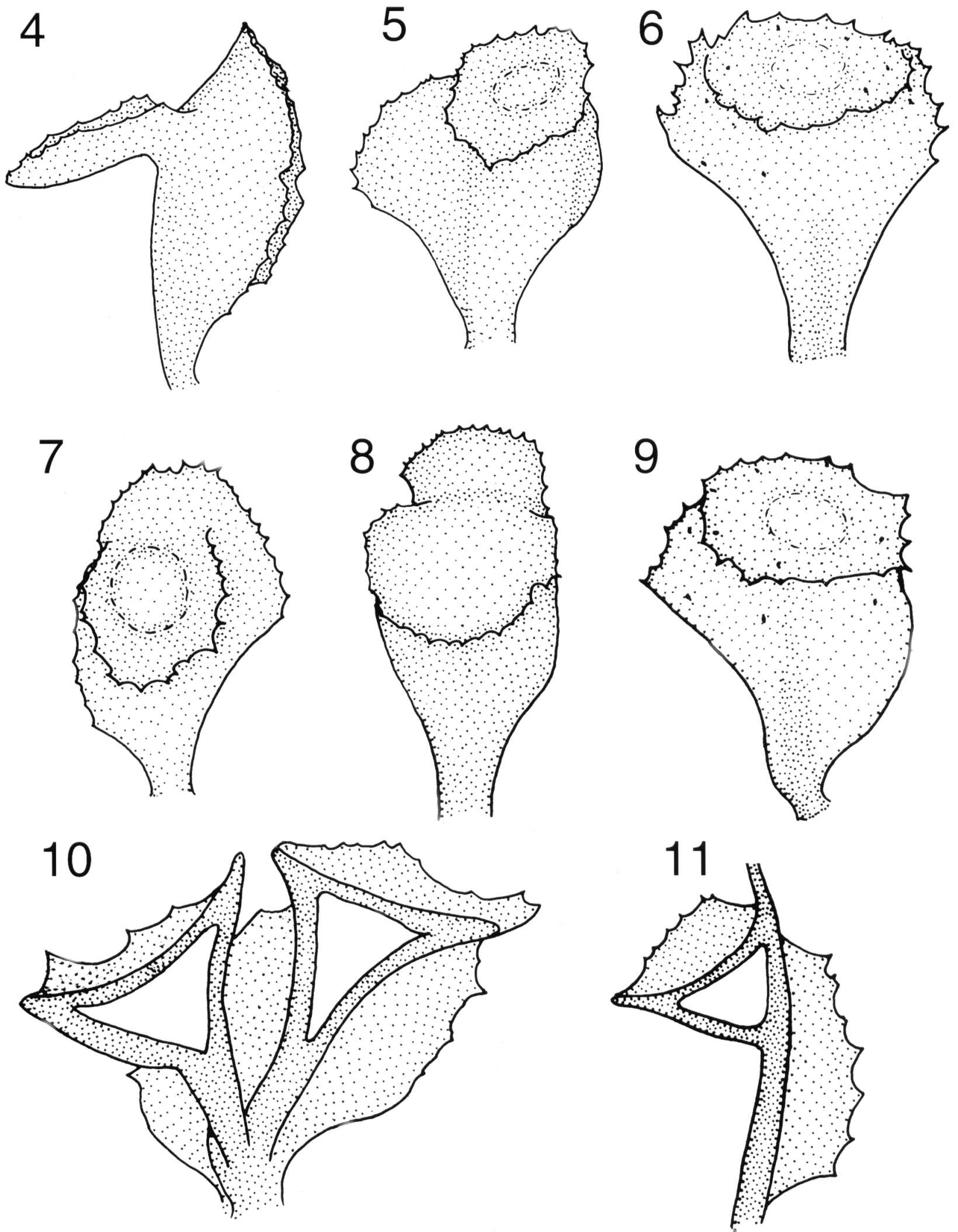

Figs 4-11. Turbinaria foliosa. 4. Side-view of leaf. 5-9. Adaxial and abaxial views of leaves, some with air vesicles. 10. Cut-open leaf with air vesicle. 11 . Half of a cut-open leaf. Holotype. 


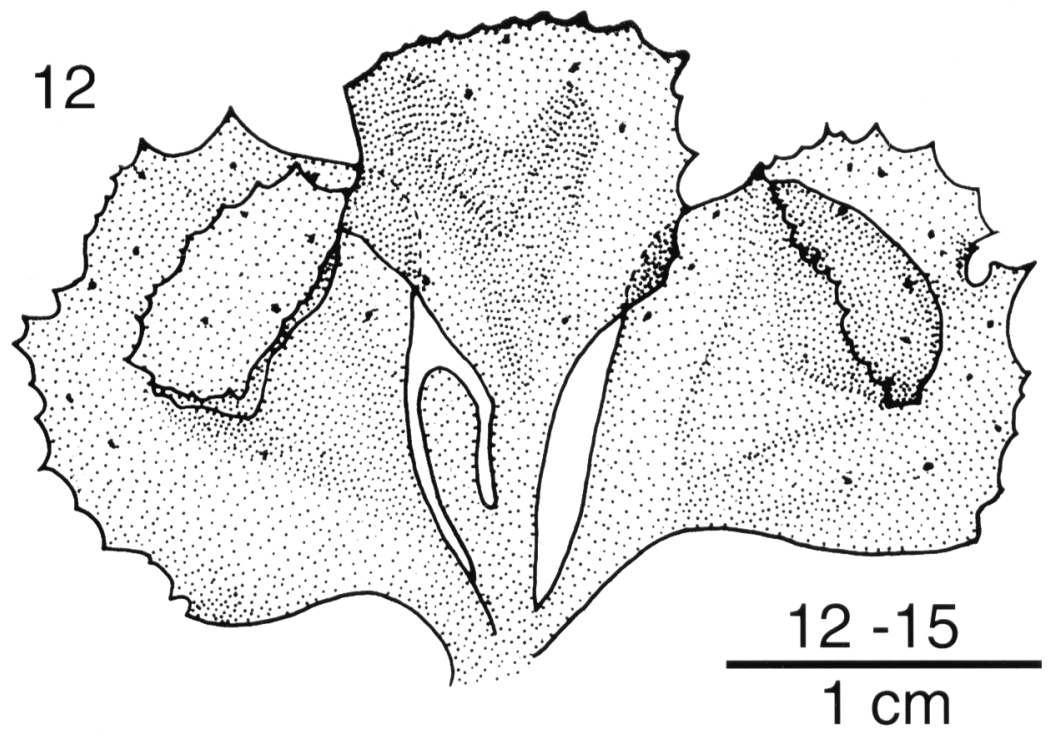

\section{3}
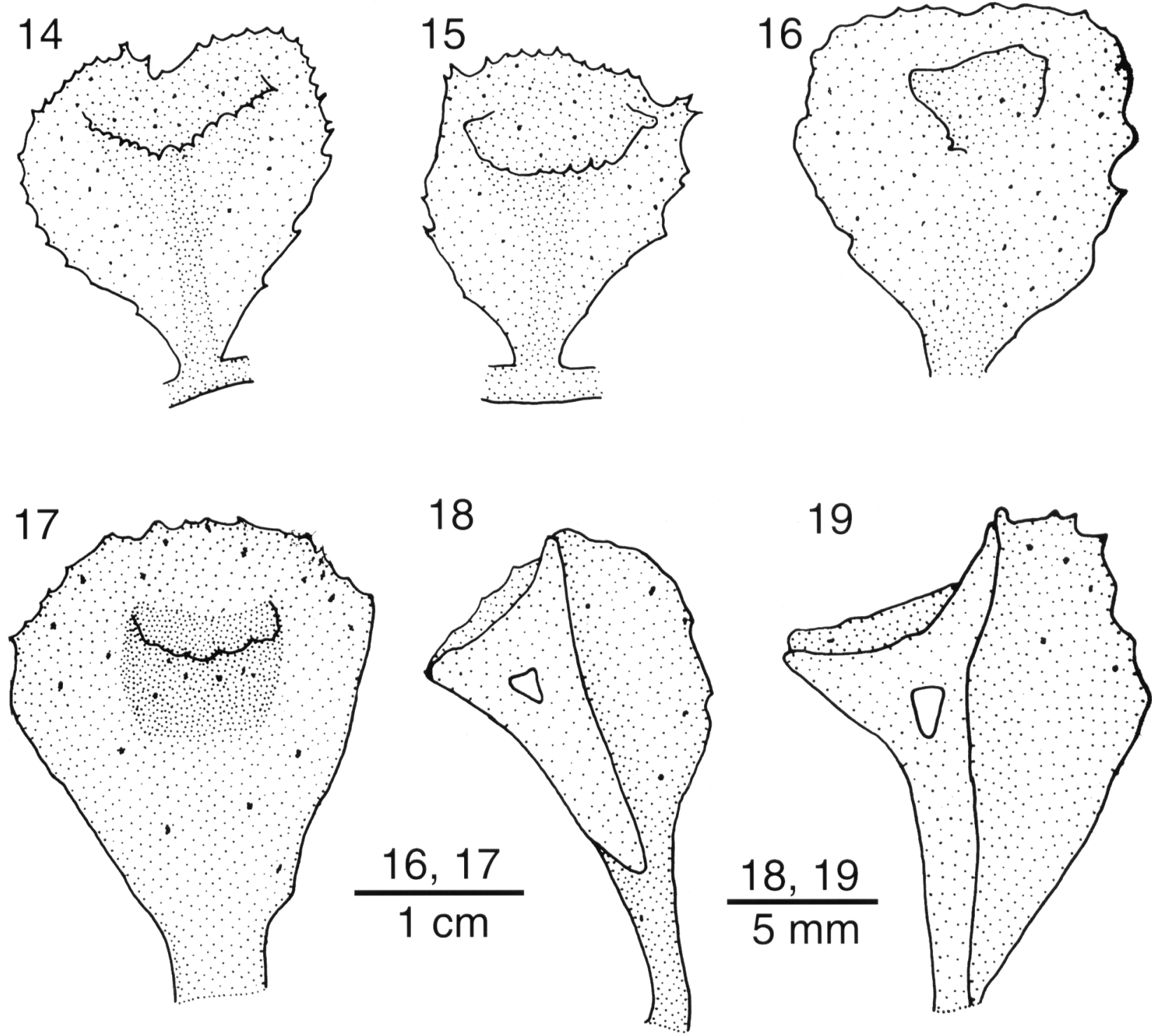

Figs 12-19. Turbinaria foliosa. 12. Cluster of leaves showing the position of the inflated projection. 13-16. Various leaves with minimally developed projections. 17. Abaxial view of leaf. 18. Side-view of same leaf in 17, but now cut open. 19. Side-view of a different cut-open leaf. 12-16: coll. 10092000-03-21; 17-19: coll. 28092001-25-02. 


\section{DISCUSSION}

Lamouroux (1825) is credited with validating the genus Turbinaria, when he recognized several Sections in his earlier treatment (Lamouroux 1813) of Fucus at the generic rank. The second Section of Fucus was delineated as Turbinaria and distinguished as having leaves that were 'turbinées et vésiculeuses' (turbinate and vesiculose). The only named species included in the second Section of Fucus was Fucus turbinatus Linnaeus. Although Turbinaria is a widespread tropical genus, it is relatively species-poor in comparison with the closely related genus Sargassum, which contains 'nearly 500 described species' distributed in temperate and tropical regions (Yoshida 1983, 1989). Some 17 species are currently assigned to Turbinaria (see Appendix I). Roughly half of these species have fairly broad distributions in tropical waters, but the other half have quite restricted regional distributions. The habit of $T$. foliosa differs from the great majority of species in the genus, which is that of an erect axis attached to the substratum, with a densely branched hapterous system and with compactly arranged leaves giving a conical appearance, for example, the species depicted by Jaasund (1976). There is some evidence that the growth form is correlated with the habitat. According to Tsuda (1972), two growth forms of $T$. ornata are present in Guam. A turgid, unbranched or sparingly branched form reaching only up to $10 \mathrm{~cm}$ in height and with relatively large leaves $(10-15 \mathrm{~mm}$ wide) is restricted to the exposed reef margins, whereas a looser, profusely branched form reaching up to $40 \mathrm{~cm}$ in height and with relatively smaller leaves $(7-10 \mathrm{~mm}$ wide) is restricted to the protected inner reef flats. Another species with a relatively loose, open habit is Turbinaria parvifolia (Tseng and Lu 2000, pl. II, fig. 1), but the leaves in that species are quite small and have a definite turbinate shape. Other workers have demonstrated the effect of the environment on morphology and reproductive status. In a study of T. ornata in French Polynesia, Payri (1984) observed that specimens in a more exposed site had decreased branching, smaller overall size, less individual weight, but larger holdfasts than specimens in sheltered and moderately exposed sites. The dwarfed (exposed) plants became reproductive earlier. In the reefs of Tahiti, $T$. ornata showed invasive characteristics, its broad morphological variability correlated with its high ecological tolerance (Stiger and Payri 1999). Wave action controlled both its thallus and phenological plasticity, greater exposure on the reef resulting in thallus size reduction and reproductive enhancement.

Barton (1891) thought that the leaf was 'reduced to its simplest form' in Turbinaria murrayana and Turbinaria tricostata, two species that lacked vesicles, but had a leaf terminating in a shield or disc supported by a petiole, thus, a leaf with a peltate appearance. The leaves in other species were complicated by the addition of a vesicle, or the petiole was ridged or winged in some species. Turbinaria foliosa appears to be conservative in the sense that its leaves are the least turbinate or peltate in the genus. The shape of the leaf in the new species is the feature that distinguishes it from other species in the genus. In the morphological range of the leaves in $T$. foliosa, one can envision a series leading from a flat, foliose leaf toward the turbinate leaf shape that characterizes most Turbinaria species. One can also see in $T$. foliosa a gradation in the development of the air vesicle, with solid projections to projections with a minimal air space, to projections with a conspicuous air vesicle.

A 'Turbinaria sp.' was described from Palau Islands (Western Caroline Islands) by Ajisaka and Kilar (1990) as co-occurring with $T$. ornata. The hemi-peltate blades of Turbinaria sp. were what distinguished it from other species in the genus. Vesicles were usually absent, but, when present, were located on the basal parts of marginal blades. Their plants were fertile; the racemose receptacles were attached to the upper sides of the blade stalks. Ajisaka and Kilar (1990) noted some similarity between the 'ordinal blades' of Turbinaria sp. to the cauline blades of $T$. ornata. It was uncertain whether these two entities represented distinct species or not. In regard to the Omani situation, $T$. foliosa was growing without any other Turbinaria at its two collection sites. Turbinaria ornata f. ecoronata was reported from Muscat, the Gulf of Oman (Wynne and Jupp 1998), and T. ornata f. evisculosa was reported from Al Hallaniyah Island off the Dhofar coast (Wynne 2001a).

The new species appears to be most closely related to Turbinaria triquetra (J. Agardh) J. Agardh in Kützing and Turbinaria papenfussii W. R. Taylor (Taylor 1964), both species with distributions restricted to the Red Sea. The leaves in those two species are strongly alate, but their leaves are triquetrous and strongly turbinate, unlike the more foliose nature of the leaves in $T$. foliosa.

Some species of Sargassum have leaves with duplicated margins such that they form distal pockets or cups. The distal leaf margins are cup-shaped in Sargassum duplicatum Bory and Sargassum turbinatifolium Tseng et Lu, whereas they form two rows of serrations in Sargassum cristaefolium C. Agardh and Sargassum crassifolium J. Agardh (Ajisaka et al. 1997; Trono 1997). Yet, in these species, the leaves with duplicated margins and sometimes turbinate shapes are separate from the vesicles. This presence of differentiated leaves and vesicles is what places them in Sargassum and not in Turbinaria. In addition, according to Tseng and Lu (1997) S. cristaefolium, S. crassifolium, and $S$. duplicatum all have discoid holdfasts, thus different from the branching hapterous holdfast of $T$. foliosa. The vesicles in S. crassifolium range from narrowly alate to having broad wings (phyllocystous) (Ajisaka et al. 1997). 
There are two species of Sargassum with specific epithets that allude to Turbinaria, namely, S. turbinarioides Grunow (1915) and S. turbinatifolium Tseng and Lu (1979). In regard to S. turbinarioides, Ajisaka et al. (1997) stated that a search for the type specimen in Vienna (W) 'was unsuccessful'. They further stated that, in their opinion, because Grunow's original description does 'not clearly describe the material at hand, we choose to use the name $S$. turbinatifolium.' Thus, they treated reports of $S$. turbinarioides by Pham-Hoàng (1967) and by Trono (1992) as S. turbinatifolium for the purported reason that the continued used of the name $S$. turbinarioides 'does not contribute to stable taxonomy'. Yet, they ignored the fact that Grunow's description of $S$. turbinarioides (Grunow 1915) is as complete as for any other species of Sargassum that he described. But more to the point, Dr R. Haroun was able to locate S. turbinarioides in W and sent me photocopies of the material labeled 'Typus'. There are three specimens bearing the etiquette 'Noumea, New Caledonia, November 1884 leg. A. Grunow', along with Grunow's handwritten Latin description and his sketches of axes, leaves, vesicles and receptacles. Grunow (1915) described the plants to be up to $36 \mathrm{~cm}$ long, with crowded and spreading branches, and leaves to be small $(1 \mathrm{~cm}$ long, $6 \mathrm{~mm}$ broad), polymorphic, strongly dentate, costate, sometimes broadly cuneate, obtuse, seminerved or nerveless and dilated suddenly from a rather long stalk into a broad, oblique, subinvolute, dentate blade. Vesicles were described as spherical, $6 \mathrm{~mm}$ in diameter, awnless or crowned with a small subfoliaceous apiculum, borne on a flat petiole, whereas receptacles were androgynous, subfastigiate-paniculate or subcymose, spinulose. Tseng and Lu (1979, 1999) described plants of their S. turbinatifolium to be $35-40 \mathrm{~cm}$ tall, the axes bearing small but rigid turbinate leaves $(8-10 \mathrm{~mm}$ long, 5-8 mm wide), with strongly conduplicate upper parts with sharp teeth. Vesicles were said to be spherical, 4-5 mm in diameter and winged, and receptacles were androgynous and ancipitate. Although the many shared characteristics of $S$. turbinarioides and S. turbinatifolium are obvious, both of these species belong to Sargassum in that the spherical vesicles and the leaves are discrete entities typical of the genus.

\section{ACKNOWLEDGMENTS}

I wish to acknowledge the Algal Biodiversity Project of Oman (1999-2002), funded by a British Government Darwin Initiative grant for the Survival of Species. The project was managed by HTS Development Ltd, UK, working with the Natural History Museum of Muscat, Oman, and supported by the Natural History Museum of London and the Herbarium of the University of Michigan. The Darwin Initiative is part of the British Government Department of Environment Transport and the Regions (DETR). I am grateful to the following individuals for their contributions to this research: Dr Lynne Barratt, Mr Glenn Richards and Ms Emma Dodsworth, all of whom were personnel of HTS Development Ltd, and to Dr Henry Ford, Mrs Gianna Minton, and $\mathrm{Mr}$ Tim Collins for their participation on the collecting trips. I thank Dr Ricardo Haroun, Universidad de Las Palmas, Spain, for sending me photocopies of the specimen of $S$. turbinarioides Grunow, which he was able to locate in W. I also thank Dr Uwe Passauer, curator of the Botanical Collection at the Museum, for his guidance. Dr Bruno de Reviers kindly provided me with information about syntype specimens of Turbinaria denudata in PC. I am grateful to Mr David Bay for his photographic skills.

\section{REFERENCES}

Agardh, C. A. 1821. Species Algarum, Vol. Primum Pars Prima Fucoideae. Publisher unknown, Gryphiswaldiae.

Agardh, J. G. 1848. Species Genera et Ordines Algarum, Vol. I. Algas Fucoideas Complectens. Lund, viii +363 pp.

Ajisaka, T. and Kilar, J. A. 1990. Turbinaria sp. (Phaeophyceae, Sargassaceae) from Iwayama Bay, Palau Islands (Western Caroline Islands). South Pacific Study (Kagoshima Univ.) 10: 235-40.

Ajisaka, T., Nang, H. Q., Dinh, N. H. et al. 1997. Taxonomic and nomenclatural study of Sargassum duplicatum Bory and related species. In Abbott, I. A. (Ed.) Taxonomy of Economic Seaweeds with References to Some Pacific Species 6. Publ. Calif. Sea Grant College System, La Jolla, CA, pp. 27-36.

Barton, E. S. 1891. A systematic and structural account of the genus Turbinaria, Lamx. Trans. Linn. Soc. Lond. (Bot.) 3: 215-26.

Børgesen, F. 1932. A revision of Forsskål's algae mentioned in Flora Ægyptiaco-arabica and found in his Herbarium in the Botanical Museum of the University of Copenhagen. Dansk. Botanisk. Arkiv. 8: 1-14 + [1], 1 pl.

Børgesen, F. 1933. Some Indian green and brown algae especially from the shores of the Presidency of BombayIII. J. Indian Bot. Soc. 12: 1-16.

Bory de Saint-Vincent, J. B. G. M. 1826-1829. Cryptogamie. In Duperrey, L. J. (Ed.) Voyage Autour du Monde, Exécuté par Ordre du Roi, sur la Corvette de sa Majesté, la Coquille, Pendant les Années 1822, 1823, 1824 et 1825, Vol. 6. Histoire Naturelle, Botanique. Publisher unknown, Paris, 301 pp., Atlas. pls 1-13, 13 bis, 14-38. [pp. 1-96 (1827), 97-200 (1828), 201-301 (1829); Atlas (1826).]

Calumpong, H. P. and Meñez, E. G. 1997. Field Guide to the Common Mangroves, Seagrasses and Algae of the Philippines. Bookmark, Inc., Makati City, Philippines, 197 pp.

Chiang, Y. -M. 1962. Marine algae collected from Penghu (Pescadores). Taiwania 8: 167-80.

Coppejans, E., De Clerck, O. and Van den heede, C. 1995. Annotated and illustrated survey of the marine macroalgae 
from Motupore Island and vicinity (Port Moresby area, Papua New Guinea). II. Phaeophyceae. Belg. J. Bot. 128: 176-97.

Coppejans, E., Leliaert, F. and De Clerck, O. 2000. Annotated list of new records of marine macroalgae for Kenya and Tanzania, since Isaac's and Jaasund's publications. Biol. Jaarb. Dodonaea 67: 31-93.

Dawson, E. Y. 1954. Marine plants in the vicinity of the Institut Océanographique de Nha Trang, Viét Nam. Pac. Sci. 8: 373-469.

De Clerck, O. and Coppejans, E. 1996. Marine algae of the Jubail Marine Wildlife Sanctuary, Saudi Arabia. In Krupp, F., Abuazinada, A. H. and Nader, L. A. (Eds) A Marine Wildlife Sanctuary for the Arabian Gulf. Environmental Research and Conservation Following the 1991 Gulf War Oil Spill. National Commission for Wildlife Conservation and Development, Riyadh and Senckenberg Research Institute, Frankfurt A. M. pp. 199-289.

Forsskål, P. 1775. Flora Aegyptiaco-Arabica. Mölleri, Havniae (Copenhagen), $32+$ cxxvi + 219 pp.

Fritsch, E. F. 1959. The Structure and Reproduction of the Algae, Vol. II. Foreword, Phaeophyceae, Rhodophyceae, Myxophyceae (Reprinted, 1st Edn 1945). University Press, Cambridge.

Gepp, A. and Gepp, E. S. 1908. Marine algae (Chlorophyceae and Phaeophyceae) and marine phanerogams of the 'Sealark' expedition, collected by J. Stanley Gardiner, M.A., F.R.S., F.L.S. Trans. Linn. Soc. Lond., 2nd Ser., Bot. 7: 163-88.

Gmelin, S. G. 1768. Historia Fucorum. Typographia Academiae Scientiarum, Petropoli (St. Petersburg). xii $+239+6$ pp.

Greuter, W., McNeill, J., Barrie, F. R. et al. (Eds) 2000. International Code of Botanical Nomenclature (Saint Louis Code) adopted by the Sixteenth International Botanical Congress St Louis, Missouri, July-August 1999. Regnum Vegetabile 138: xviii + 474 pp.

Grunow, A. 1915. Additamenta ad cognitionem Sargassorum. Verh. Zool. Bot. Gesell. Wien 65: 329-448.

Harvey, W. H. 1860. Phycologia Australica, Vol. III. L. Reeve, London, pls 121-80.

Holmgren, P. K., Holmgren, N. H. and Barnett, L. C. 1990. Index Herbariorum, Part I. The Herbaria of the World. New York Botanical Garden, Bronx, N.Y. Regnum Vegetabile 120: $x+693 \mathrm{pp}$.

Howe, M. A. 1920. Algae. In Britton, N. L. and Millspaugh. C. F. (Eds) The Bahama Flora. Published by the Authors, New York. pp. 553-618.

Huisman, J. M. 2000. Marine Plants of Australia. University of Western Australia Press, Nedlands.

Ismail, A. 1995. Rympai laut Malaysia. Dewan Bahasa dan Pustaka, Kementerian Pendidikan Malaysia, Kuala Lumpur.

Jaasund, E. 1976. Intertidal Seaweeds in Tanzania. A Field Guide. University of Troms $\varnothing$, Troms $\varnothing$.

Jaasund, E. 1977a. Marine algae in Tanzania. V. Bot. Mar. 20: 333-8.

Jaasund, E. 1977b. Marine algae in Tanzania. VIII. Bot. Mar. 20: $509-20$.
Kützing, F. T. 1849. Species Algarum. Brockhaus, Lipsiae (Leipzig).

Kützing, F. T. 1860. Tabulae Phycologicae, Vol. 10. Nordhausen, iv $+39 \mathrm{pp}$.

Küntze, O. 1898. Revisio Generum Plantarum, Pt 3[3]. Publisher unknown, Leipzig, pp. 1-576.

Lamouroux, J. V. 1813. Essai sur les genres de la famille des Thalassiophytes non articulées. Ann. Mus. Hist. Nat. (Paris) 20: 21-47, 115-39, 267-93.

Lamouroux, J. V. 1825. Fucacées, Fucaceae. Dictionnaire Classique d'Histoire Naturelle 7: 66-71.

Linnaeus, C. 1753. Species Plantarum, Vol. 2. Impensis Laurentii Salvii, Holmiae, pp. 561-1200 (+ 1-31).

Littler, D. S. and Littler, M. M. 2000. Caribbean Reef Plants. An Identification Guide to the Reef Plants of the Caribbean, Bahamas, Florida and Gulf of Mexico. OffShore Graphics, Inc., Washington, DC.

Littler, D. S., Littler, M. M., Bucher, K. E. and Norris, J. N. 1989. Marine Plants of the Caribbean. A Field Guide from Florida to Brazil. Smithsonian Institution Press, Washington, DC.

Lu, B. and Tseng, C. K. 1983. Phaeophyta. In Tseng, C. K. (Ed.) Common Seaweeds of China. English Edn. Science Press, Beijing, pp. 168-243.

Montagne, J. F. C. 1857. Huitième centurie de plantes cellulaires nouvelles, tant indigènes qu'exotiques. Ann. Sci. Nat. Bot., Sér. IV 7: 134-53.

Nizamuddin, M. and Campbell, A. C. 1995. Glossophorella, a new genus of the family Dictyotaceae (DictyotalesPhaeophyta) and its ecology from the coast of the Sultanate of Oman. Pak. J. Bot. 27: 257-62.

Payri, C. 1984. Variations biologiques et morphologiques en fonction du milieu chez Turbinaria ornata (Turner) J. Agardh (Pheophycées) du récif de Tiahura - Île de Moorea - Polynésie Française. Bot. Mar. 27: 327-33.

Payri, C., N'Yeurt, A. de R. and Orempuller, J. 2000. Algues de Polynésie Française. Algae of French Polynesia. Au Vent des Iles, Editions, Tahiti, [4] + 320 pp.

Pham-Hoàng, H. 1967. Contribution à l'étude des algues littorales du Vietnam: la genre Sargassum. Ann. Fac. Sci. Saigon pp. 259-332 (not seen).

Pham-Hoàng, H. 1969. Rong Biên Viêtnam. Marine Algae of South Vietnam. Trung-tâm Hoc-liéû Xuât-bán, Saigon. (In Vietnamese.)

Ramirez, M. E. and Santelices, B. 1991. Catálogo de las algas marinas bentónicas de la costa temperada del Pacífico de Sudamérica. Monografías Biológicas 5. Facultad de Ciencias Biológicas Pontificia Universidad Católica de Chile, Santiago.

Ruprecht, F. J. 1849. Die Vegetation des Rothes Meeres. Mém. Acad. Imp. Sci. Saint-Pétersbourg. Sér. 6, Sci. Nat. Bot. 6: 71-84.

Sartoni, G. 1975. Contributo alla conoscenza della flora algale bentonica di Sar Uanle (Somalia meridionale). Giorn. Bot. Ital. 108: 281-303.

Seagrief, S. C. 1980. Seaweeds of Maputaland. In Bruton, M. N. and Cooper, K. H. (Eds) Studies on the Ecology of 
Maputaland. Rhodes University and The Natal Branch of The Wildlife Society of Southern Africa, Grahamstown, pp. 18-41.

Silva, P. C., Meñez, E. G. and Moe, R. L. 1987. Catalog of the benthic marine algae of the Philippnes. Smithson. Cont. Mar. Sci. 27. iv + 179 pp.

Silva, P. C., Basson, P. W. and Moe, R. L. 1996. Catalogue of the benthic marine algae of the Indian Ocean. Univ. Calif. Publ. Bot. 79. xiv +1259 pp.

Sonder, O. G. 1845. Nova algarum genera et species, quas in itinere ad oras occidentales Novae Hollandiae, collegit L. Preiss, Ph. Dr. Bot. Zeit. 3: 49-57.

Stiger, V. and Payri, C. E. 1999. Spatial and seasonal variations in the biological characteristics of two invasive brown algae, Turbinaria ornata (Turner) J. Agardh and Sargassum mangarevense (Grunow) Setchell (Sargassaceae, Fucales) spreading on the reefs of Tahiti (French Polynesia). Bot. Mar. 42: 295-306.

Taylor, W. R. 1950. Plants of Bikini and other Northern Marshall Islands. University of Michigan Press, Ann Arbor.

Taylor, W. R. 1960. Marine Algae of the Eastern Tropical and Subtropical Coasts of the Americas. University of Michigan Press, Ann Arbor.

Taylor, W. R. 1964. The genus Turbinaria in eastern seas. J. Linn. Soc., Bot. 58: 475-87.

Taylor, W. R. 1965. A new Turbinaria from the Red Sea district. Israel J. Bot. 14: 97-100.

Taylor, W. R. 1966. Notes on Indo-Pacific Turbinarias. Hydrobiologia 28: 91-100.

Trono, G. C. Jr. 1992. The genus Sargassum in the Philippines. In Abbott, I. A. (Ed.) Taxonomy of Economic Seaweeds with References to some Pacific and Western Atlantic Species 3. Publ. Calif. Sea Grant College System, La Jolla, CA, pp. 43-94.

Trono, G. C. Jr. 1997. Field Guide and Atlas of the Seaweed Resources of the Philippines. Bookmark, Inc., Makati City, Philippines.

Trono, G. C. Jr. and Ganzon-Fortes, E. T. 1980. An Illustrated Seaweed Flora of Calatagan, Batangas, Philippines. Filipinas Foundation, Inc., and the University of the Philippines Marine Sciences Center, Manila.

Tseng, C. K. and Lu, B. 1979. Studies on the Sargassaceae of the Xisha Islands, Guangdong Province, China. II. Stud. Mar. Sin. 15: 1-12.

Tseng, C. K. and Lu, B. 1983. Two new brown algae from the Xisha Islands, South China Sea. Chin. J. Ocean. Limn. 1: 185-88.

Tseng, C. K. and Lu, B. 1997. Studies on the glomerulate Sargassum of China: IV. Series of Platycarpae. In Abbott, I. A. (Ed.) Taxonomy of Economic Seaweeds with References to Some Pacific Species 6. Publ. Calif. Sea Grant College System, La Jolla, CA, pp. 9-25.

Tseng, C. K. and Lu, B. 1999. Studies on the biserrulic Sargassum of China: II. The series Coriifoliae J. G. Agardh. In Abbott, I. A. (Ed.) Taxonomy of Economic Seaweeds with references to some Pacific species 7. Publ. Calif. Sea Grant College System, La Jolla, CA, pp. 3-22.

Tseng, C. K. and Lu, B. 2000. Fucales. Flora Algarum Marinarum Tomus III Phaeophyta, No. II. Science Press, Beijing, i-xi, 1-[238] pp, pls I-XXXI.

Tsuda, R. T. 1972. Marine benthic algae of Guam I. Phaeophyta. Micronesica 8: 87-115.

Turner, D. 1807-1808. Fuci, Vol. 1. London, [iii+] 164 [+2] pp.

Verheij, W. and Prud'homme van Reine, W. 1993. Seaweeds of the Spermonde Archipelago, SW Sulawesi, Indonesia. Blumea 37: 385-510.

Wynne, M. J. 1998. Champia gigantea and Lomentaria strumosa (Rhodymeniales): two new red algae from the Sultanate of Oman. Bot. Mar. 41: 571-80.

Wynne, M. J. 1999a. Pseudogrinnellia barrattiae gen. et sp. nov., a new member of the red algal family Delesseriaceae from the Sultanate of Oman. Bot. Mar. 42: 37-42.

Wynne, M. J. 1999b. New records of benthic marine algae from the Sultanate of Oman. Contr. Univ. Mich. Herb. 22: 189-208.

Wynne, M. J. 2000. Further connections between the benthic marine algal floras of the northern Arabian Sea and Japan. Phycol. Res. 48: 211-20.

Wynne, M. J. 2001a. New records of benthic marine algae from the Sultanate of Oman, northern Arabian Sea. II. Nova Hedwigia 72: 347-74.

Wynne, M. J. 2001b. New records of benthic marine algae from the Sultanate of Oman, northern Arabian Sea. III. Cont. Univ. Mich. Herb. 23: 389-406.

Wynne, M. J. (2002). A description of Plocamium fimbriatum sp. nov. (Plocamiales, Rhodophyta) from the Sultanate of Oman, with a census of currently recognized species in the genus. Nova Hedwigia 75: 333-356.

Wynne, M. J. and de Jong, Y. S. D. M. 2002. Dipterocladia arabiensis sp. nov. (Dasyaceae, Rhodophyta) from the Sultanate of Oman. Bot. Mar. 45: 77-86.

Wynne, M. J. and Jupp, B. P. 1998. The benthic marine algal flora of the Sultanate of Oman: new records. Bot. Mar. 41: 7-14.

Wynne, M. J. and Leliaert, F. 2001. Pedobesia simplex (Kützing) comb. nov. (Chlorophyta), a new name for $P$. lamourouxii and its first report from the Indian Ocean. Cryptog. Algol. 22: 3-14.

Yamada, Y. 1925. Studien über die Meeresalgen von der Insel Formosa. 2. Phaeophyceae. Bot. Mag. (Tokyo) 39 239-54.

Yamada, Y. 1950. A list of marine algae from Ryukyusho, Formosa, I. Sci. Papers Inst. Algol. Res., Fac. Sci., Hokkaido Univ. 3: 173-94.

Yoshida, T. 1983. Japanese species of Sargassum subgenus Bactrophycus (Phaeophyta, Fucales). J. Fac. Sci., Hokkaido Univ., Ser. V (Botany) 13: 99-246.

Yoshida, T. 1989. Taxonomy of Sargassum. Korean J. Phycol. 4: $107-10$.

Yoshida, T. 1991. Catalogue of the type specimens of algae preserved in the Herbarium, Department of Botany, the 
University Museum, the University of Tokyo. Materials Report No. 24, The University Museum, The University of Tokyo, Tokyo.

Yoshida, T. 1998. Marine Algae of Japan. Uchida Rokakuho Publishing Co., Ltd, Tokyo. (In Japanese.)

\section{APPENDIX I}

\section{Currently recognized species of Turbinaria}

Turbinaria condensata Sonder in Kützing (1860) [type locality: 'in mari chinensi']; tax. syn.: Turbinaria dentata E. S. Barton (1891) [type locality: Macassar, SW Celebes I., Indonesia]. This synonymy was proposed by Gepp and Gepp [née Barton] (1908). Icon.: Kützing (1860, pl. 69: II); Barton (1891, pl. 54, fig. 5, as T. dentata); Taylor (1964, pl. 2, figs 18-28).

Turbinaria conoides (J. Agardh) Kützing (1860); basionym: Turbinaria vulgaris J. Agardh var. conoides J. Agardh (1848) [syntype localities: on the shores of India, China, Ceylon, and Western Australia]; tax. syn.: Turbinaria heterophylla Kützing (1860) [type locality: Sunda Strait, between the islands of Sumatra and Java]. This synonymy was proposed by Taylor (1964). Icon: Kützing (1860, pl. 69: I) Icon.: Kützing (1860, pls 66: II, 69: I, as T. heterophylla); Barton (1891, pl. 54, fig. 1); Taylor (1964, pl. 2, figs 1-8); PhamHoàng, 1969, fig. 3.53); Jaasund (1976, fig. 100); Trono and Ganzon-Fortes (1980: 55); Lu and Tseng (1983, pl. 121, fig. 3); Verheij and Prud'homme van Reine (1993, pl. 12, fig. 9); Coppejans et al. (1995, fig. 36); Ismail (1995, fig. 8.26); Calumpong and Meñez (1997: 138); Trono (1997, fig. 98); Tseng and Lu (2000, pl. 1, fig. 3).

Børgesen (1932) initially applied the name Turbinaria turbinata (Linn.) Børgesen nom. illeg. to this entity, but later (Børgesen 1933) he realized that the combination had already been proposed (Küntze 1898) for the Linnean concept based on Hans Sloan's Jamaican material.

forma laticuspidata W. R. Taylor (1964) [type locality: Cebu Island, Cebu Province, the Philippines]. Icon.: Taylor (1964, pl. 2, figs 9-12).

forma retroflexa W. R. Taylor (1964) [type locality: Tandayong Island, Pangasinan Province, the Philippines]. Silva et al. (1987) stated that this forma is invalidly published because an illustration was not provided at that time.

Turbinaria crateriformis W. R. Taylor (1966) [type locality: Diani Beach, 20 miles S. of Mombasa, Kenya]. Icon.: Taylor (1966, text-figs 14-19, pl. 1, fig. 1); Jaasund (1976, fig. 101).

Turbinaria decurrens Bory de Saint-Vincent (1828) [type locality: 'Flottants...entre les îles de la Société et la Nouvelle-Guinée']; tax. syn.: Turbinaria vulgaris J. Agardh nom. illeg. (1848). The name T. vulgaris is illegitimate in that it was initially superfluous because one of the varieties included in it by J. Agardh was var. decurrens (Bory de Saint-Vincent) J. Agardh, an entity previously recognized as a species. Icon.: Turner (1807-1808, pl. 24, fig. b); Kützing (1860, pl. 68: ।; pl. 68: II as 'Turbinaria triquetra' fide Taylor 1964); Taylor (1964, pl. 1, figs 22-8); Pham-Hoàng (1969, fig. 3.48); Jaasund (1976, fig. 104); Coppejans et al. (1995, fig. 37); Ismail (1995, fig. 8.28); Trono (1997, fig. 99). According to Taylor (1964), the many records of $T$. decurrens from the Red Sea apply to T. triquetra.

Turbinaria denudata Bory de Saint-Vincent (1828) [syntype localities: various sites in the Pacific and Indian oceans and the Caribbean Sea]. J. Agardh (1848) and Barton (1891) interpreted T. denudata to be a heterogeneous collection of taxa, including Turbinaria ornata, Turbinaria conoides, and Turbinaria turbinata. That fact caused Silva et al. (1987) to point out that $T$. denudata should be lectotypified on the basis of authentic specimens in PC and depending on the specimen chosen, $T$. denudata would become a synonym of $T$. turbinata or displace either $T$. conoides or T. ornata. Dr Bruno de Reviers located a total of three syntype specimens in Bory's herbarium now located within the Thuret-Bornet herbarium in PC. All three had been determined by Bornet to be $T$. ornata. (i) Nr. TA8060 collection by d'Urville at Otaiti (French Polynesia) and by Lesson at Bora Bora (French Polynesia) in 1825. This is consistent with pg. 118 of the protologue. (ii) Nr. TA8062 collected by Lesson in 1825 at Concepción, Chile. This is consistent with pg. 118 of the protologue. (iii) Nr. TA8063 collected by d'Urville in 1825 at Concepción, Chile. This is consistent with p. 118 of the protologue.

One significant problem is that two of these three collections were allegedly made in Chile, but the genus Turbinaria does not occur in Chile (Ramirez and Santelices 1991). Thus, chosing Nr. TA8060 (which has specimens from two sites) as the lectotype would seem reasonable, but the fact that $T$. denudata has been regarded as being heterogeneous would argue for treating it as a nomen ambiguum. In light of the Code's admonition in its preamble to retain stability and to avoid ambiguity (Greuter et al. 2000), nomenclature would be best served by rejecting the name $T$. denudata.

var. javanica Montagne (1857) [type locality: Batavia = Jakarta, Java, Indonesia $]$.

Turbinaria elatensis W. R. Taylor (1965) [type locality: 6 km S. of Elat, Sinai, Egypt, Red Sea]. Icon.: Taylor (1965, figs 1-11).

Turbinaria filamentosa Yamada (1925) [type locality: Garanbi, Formosa/Taiwan]. Icon.: Yamada (1925, fig. 1).

Turbinaria gracilis Sonder (1845) [type locality: Western Australia]. Icon.: Kützing (1860, pl. 70); Taylor (1964, pl. 3, figs 13-21); Pham-Hoàng (1969, fig. 3.52); Yoshida (1991, pl. 60); Huisman (2000, p. 226). 
Turbinaria kenyaensis W. R. Taylor (1966) [type locality: Diani Beach, 20 miles S. of Mombasa, Kenya]. Icon.: Taylor (1966, text-figs 1-13, pls. 1, fig. 2); Jaasund (1976, fig. 102).

Turbinaria luzonensis W. R. Taylor (1964) [type locality: Mulanay, Luzon Island, Quezon Province, the Philippines]. Icon.: Taylor (1964, pl. 2, figs 13-17).

Turbinaria murrayana E. S. Barton (1891) [type locality: New Guinea]. Icon.: Barton (1891, pl. 54, fig. 2); Gepp and Gepp (1908, pl. 24, figs 25,26).

Turbinaria ornata (Turner) J. Agardh (1848; basionym: Fucus turbinatus Linnaeus var. ornatus Turner (1807-1808) [type locality: not stated]. Sargassum turbinatum (Linnaus) C. Agardh var. ornatum (Turner) C. Agardh (1821); Icon.: Turner (1807-1808, pl. 24, figs c,d); Kützing (1860, pl. 66: I); Gepp and Gepp (1908, pl. 24, fig. 27); Taylor (1950, pls 53: 2, 55: 2); Dawson (1954, fig. 21); Taylor (1964, pl. 3, figs 1-6); Pham-Hoàng (1969, fig. 3. 49); Tsuda (1972, pl. 8, figs 1-3); Sartoni (1975, fig. 12); Jaasund (1976, fig. 105); Seagrief (1980, included on pl. 6); Trono and Ganzon-Fortes (1980: 57); Lu and Tseng (1983, pl. 122, fig. 1); Payri (1984, fig. 3); Verheij and Prud'homme van Reine (1993, pl. 12, fig. 7); Coppejans et al. (1995, fig. 38); Ismail (1995, fig. 8. 27); Calumpong and Meñez (1997: 137); Trono (1997, fig. 100); Huisman (2000, p. 226); Payri et al. (2000, p. 9, fig. 6; p. 149); Tseng and Lu (2000, pl. I, fig. 4).

var. ornata

forma cordata Pham-Hoàng (1969) [type locality: Viet Nam]. Icon.: Pham-Hoàng (1969, fig. 3. 51).

forma ecoronata W. R. Taylor (1964) [type locality: Strawn Island, Palmyra Atoll, central Pacific Ocean]. Icon.: Taylor (1964, pl. 3, figs 7-9).

forma evesiculosa (Barton) W. R. Taylor (1964); basionym: Turbinaria conoides var. evesiculosa E. S. Barton (1891) [type locality: islands of Edam and Enkhuizen near Batavia, NW coast of Java]. Icon.: De Clerck and Coppejans (1996, figs 75,77); Wynne (2001a, fig. 32).

forma hainanensis W. R. Taylor (1964) [type locality: Wenchang, Hainan Island, China]. Icon.: Taylor (1964, pl. 3, figs 10-12).

var. prolifera Pham-Hoàng (1969) [type locality: Viet Nam]. Icon.: Pham-Hoàng (1969, fig. 3.50).

var. serrata Jaasund nom. ined. According to Silva et al. (1996), the name of this taxon remains invalid in the lack of a Latin diagnosis (Jaasund 1976) and later in the failure to designate a type (Jaasund 1977a,b).

Turbinaria papenfussii W. R. Taylor (1964) [type locality: Romia Islet, Dahlak Archipelago, Ethiopia, Red Sea]. Icon.: Taylor (1964, pl. 1. figs 1-9).

Turbinaria parvifolia Tseng et Lu (1983) [type locality: Zhongjiandao, Xisha Islands, South China Sea].
Icon.: Lu and Tseng (1983, pl.122, fig. 2); Tseng and Lu (1983, pl. 1: 2, fig. 2; 2000, pl. II, fig. 1); Verheij and Prud'homme van Reine (1993, pl. 12, fig. 8).

Turbinaria tricostata E. S. Barton (1891) [type locality: Guadeloupe, French West Indies, Caribbean Sea]. Icon.: Barton (1891, pl. 54, fig. 3); Littler et al. (1989: 130); Littler and Littler (2000: 289).

var. weberae E. S. Barton (1891) [type locality: islands of Edam and Enkhuizen near Batavia, NW coast of Java]. Icon.: Barton (1891, pl. 54, fig. 4)

Turbinaria triquetra (J. Agardh) J. Agardh in Kützing (1849); basionym: Turbinaria vulgaris J. Agardh var. triquetra J. Agardh (1848) [type locality: Red Sea]; tax. syn.: Fucus conoides Forsskål (1775) [non Turbinaria conoides (J. Agardh) Kützing]; Turbinaria membranacea Ruprecht (1849) [type locality: Noweba, Gulf of Elat, Sinai Peninsula]; tax. syn.: Turbinaria tetraedra Ruprecht (1849) [type locality: El Tor, Gulf of Suez, Sinai Peninsula]. Icon.: Taylor (1964, pl. 1. figs 10-21).

Turbinaria turbinata (Linnaeus) Kuntze (1898); basionym: Fucus turbinatus Linnaeus (1753) [type locality: Jamaica; cf. Howe (1920)]; Sargassum turbinatum (Linnaeus) C. Agardh (1821); tax. syn.: Turbinaria trialata (J. Agardh) Kützing (1860); basionym: Turbinaria vulgaris var. trialata J. Agardh (1848) [syntype localities: in the Atlantic Ocean on the shore of Brazil and the West Indies]; tax. syn.: Turbinaria trialata var. havanensis Kützing (1860) [type locality: 'Havannah']; this synonymy was proposed by Howe (1920). Icon.: Kützing (1860, pl. 67: I). Icon.: Gmelin (1768, pl. 5, fig. 1); Turner (1807-1808, pl. 24, fig. a, non figs b-d); Taylor (1960, pl. 39, figs 3-5); Littler et al. (1989: 130); Littler and Littler (2000: 291).

Turbinaria trialata, which was described from syntype localities in the Western Atlantic (J. Agardh 1848), continues to be recognized by some workers (Yamada 1950; Chiang 1962; Yoshida 1998; Tseng and Lu 2000). Howe (1920) and Taylor (1960), however, treated it as conspecific with $T$. turbinata.

The status of Turbinaria trialata var. capensis Kützing (1860) [type locality: Cape of Good Hope, South Africa] is uncertain in that $T$. trialata is regarded as conspecific with $T$. turbinata (Howe 1920). The name $T$. trialata var. capensis persists in the literature (Silva et al. 1996).

An invalid name: Turbinaria tanzaniensis Jaasund nom. ined. According to Silva et al. (1996), the name of this taxon remains invalid in the lack of a Latin diagnosis (Jaasund 1976) and later in the failure to designate a type (Jaasund 1977a,b). Coppejans et al. (2000) reported this entity from Kenya, but the name remains invalid. 
Copyright $\odot 2002$ EBSCO Publishing 